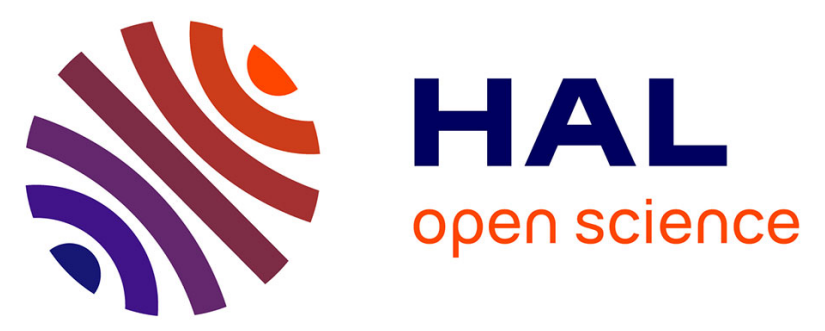

\title{
Nanoscale relationships between uranium and carbonaceous material in alteration halos around unconformity-related uranium deposits of the Kiggavik camp, Paleoproterozoic Thelon Basin, Nunavut, Canada
}

Thomas Riegler, Marie-France Beaufort, Thierry Allard, Anne-Catherine

Pierson-Wickmann, Daniel Beaufort

\section{To cite this version:}

Thomas Riegler, Marie-France Beaufort, Thierry Allard, Anne-Catherine Pierson-Wickmann, Daniel Beaufort. Nanoscale relationships between uranium and carbonaceous material in alteration halos around unconformity-related uranium deposits of the Kiggavik camp, Paleoproterozoic Thelon Basin, Nunavut, Canada. Ore Geology Reviews, 2016, 79, pp.382-391. 10.1016/j.oregeorev.2016.04.018 . insu-01312853

\section{HAL Id: insu-01312853 \\ https://hal-insu.archives-ouvertes.fr/insu-01312853}

Submitted on 9 May 2016

HAL is a multi-disciplinary open access archive for the deposit and dissemination of scientific research documents, whether they are published or not. The documents may come from teaching and research institutions in France or abroad, or from public or private research centers.
L'archive ouverte pluridisciplinaire HAL, est destinée au dépôt et à la diffusion de documents scientifiques de niveau recherche, publiés ou non, émanant des établissements d'enseignement et de recherche français ou étrangers, des laboratoires publics ou privés. 


\title{
Accepted Manuscript
}

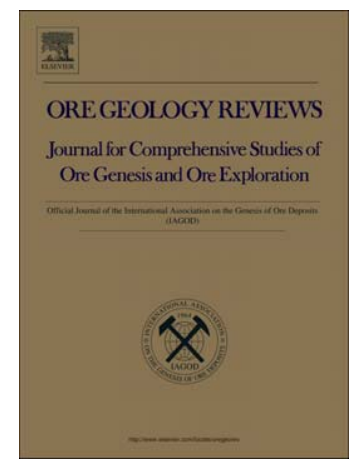

Nanoscale relationships between uranium and carbonaceous material in alteration halos around unconformity-related uranium deposits of the Kiggavik camp, Paleoproterozoic Thelon Basin, Nunavut, Canada

Thomas Riegler, Marie-France Beaufort, Thierry Allard, Anne-Catherine Pierson-Wickmann, Daniel Beaufort

\author{
PII: $\quad$ S0169-1368(15)30136-0 \\ DOI: $\quad$ doi: $10.1016 /$ j.oregeorev.2016.04.018 \\ Reference: $\quad$ OREGEO 1793 \\ To appear in: $\quad$ Ore Geology Reviews \\ Received date: 16 October 2015 \\ Revised date: $\quad 3$ April 2016 \\ Accepted date: 21 April 2016
}

Please cite this article as: Riegler, Thomas, Beaufort, Marie-France, Allard, Thierry, Pierson-Wickmann, Anne-Catherine, Beaufort, Daniel, Nanoscale relationships between uranium and carbonaceous material in alteration halos around unconformity-related uranium deposits of the Kiggavik camp, Paleoproterozoic Thelon Basin, Nunavut, Canada, Ore Geology Reviews (2016), doi: 10.1016/j.oregeorev.2016.04.018

This is a PDF file of an unedited manuscript that has been accepted for publication. As a service to our customers we are providing this early version of the manuscript. The manuscript will undergo copyediting, typesetting, and review of the resulting proof before it is published in its final form. Please note that during the production process errors may be discovered which could affect the content, and all legal disclaimers that apply to the journal pertain. 
Nanoscale relationships between uranium and carbonaceous material in alteration halos around unconformity-related uranium deposits of the Kiggavik camp, Paleoproterozoic Thelon Basin, Nunavut, Canada

Thomas Riegler ${ }^{1, *}$; Marie-France Beaufort ${ }^{2}$; Thierry Allard ${ }^{3}$; Anne-Catherine PiersonWickmann $^{4}$; and Daniel Beaufort ${ }^{1}$

(*) corresponding author, present address Trinity College Dublin, Department of Geology, College Green, Dublin 2, Ireland

(1) IC2MP, Université de Poitiers, UMR 7285, Bât. B35, 6 rue Michel Brunet, TSA 51106, 86073 Poitiers cedex 9, France

(2) Institut $\mathrm{P}^{\prime}$ - UPR 3346 Département Physique et Mécanique des Matériaux SP2MI - téléport 2 - Bd Marie et P. Curie BP 3017986962 Futuroscope Cedex - France Tel : +33 (0)5 49496834 marie.france.beaufort@univ-poitiers.fr

(3) IMPMC, UMR 7590, Université Pierre et Marie Curie, Institut de Recherche pour le Développement, Muséum d'Histoire Naturelle, 4 Place Jussieu, 75252 Paris cedex 05, France (4) OSUR - Géosciences Rennes, UMR CNRS 6118 - Campus de Beaulieu Université de Rennes 1, Avenue Général Leclerc, 35042 Rennes, cedex, France

Key words: carbonaceous material (CM); unconformity uranium (U) deposits; hydrothermal; Proterozoic

\begin{abstract}
Concentrations of $7 \% \mathrm{U}$ and $1 \% \mathrm{Cu}$ were identified in massive, brecciated, and amorphous carbonaceous materials $(\mathrm{CM})$ characterized by strongly negative values of carbon stable isotopes $\left(\delta^{13} \mathrm{C}=-39.1 \%\right.$ relative to $\left.\mathrm{PDB}\right)$. The anomalies are restricted to clay alteration halos developed in Neoarchean Woodburn Lake group metagreywacke that is the predominant host
\end{abstract}


of unconformity-related uranium (U) deposits in the Kiggavik exploration camp. Petrographic and microstructural analyses by SEM, X-Ray Diffraction, HR-TEM and RAMAN spectroscopy identified carbon veils, best described as graphene-like carbon, upon which nano-scale uraninite crystals are distributed. CM are common in U systems such as the classic Cretaceous roll-front deposits and the world-class Paleoproterozoic unconformity-related deposits. However, the unusual spatial and textural association of $U$ minerals and $C M$ described herein raises questions on mechanisms that may have been responsible for the precipitation of the $\mathrm{CM}$ followed by crystallization of $\mathrm{U}$ oxides on its surfaces. Based on the characteristics presented herein, the CMs at Kiggavik are interpreted as hydrothermal in origin. Furthermore, the nanoscale organization and properties of these graphene-like layers that host $\mathrm{U}$ oxide crystallites clearly localized $\mathrm{U}$ oxide nucleation and growth.

\section{Introduction}

Carbonaceous material (CM) of Mesoproterozoic and older ages is controversial, with two main hypothesized origins; one invokes life where solid bitumens were derived from thermal alteration of kerogen thermal evolution (e.g. Wilson and Stasiuk 2002) and the other calls upon abiotic synthesis of organic compounds, e.g. via Fischer-Tropsch type synthesis (FTT) in hydrothermal or magmatic systems (Shock 1990; Gize 1999; Foustoukos and Seyfried 2004; McCollom and Seewald 2006; Horita 2005; Ueno et al. 2004; Curiale 1986; McCollom 2013). Variously referred to as bitumen, pyrobitumen or uranoan carbon (thucholite), CM has been identified within ores and alteration halos of many Proterozoic unconformity-type uranium (U) deposits of the Athabasca Basin (Hoeve and Sibbald 1978; Hoeve et al. 1980; Hoeve and Quirt 1984; Pagel et al. 1980; Sangély et al. 2007) and vein/unconformity type (controversial) $U$ deposits of the Martin Basin (Beaverlodge District of northern Saskatchewan) (Tremblay 1972; Ruzicka 1996; Alexandre and Kyser 2006). The reduction 
potential, source and distribution of $\mathrm{CM}$ in brecciated and altered Neoarchean to Paleoproterozoic metamorphic basement and in the Paleo- to Mesoproterozoic sedimentary basins that cover and host the $\mathrm{U}$ deposits have been discussed for $\mathrm{U}$ metallogenesis (Leventhal et al. 1987; Kyser et al. 1989; Landais and Dereppe 1985; Yeo and Potter 2010; Sangély et al. 2007) with inconclusive evidence for ore control. Similar CM has been proposed as an ore controlling parameter in gold bearing veins (Mastalerz et al. 1995). In the Athabasca Basin, bitumen is considered to either post-date the main $\mathrm{U}$ mineralization stage (Wilson et al. 2002; Leventhal et al. 1987) or to be contemporaneous (Alexandre and Kyser 2006). By comparison, in the 1.74 Ga Oklo deposit of the Paleoproterozoic Franceville Basin the paragenesis clearly links bitumen, oil occurrences and U mineralization in a Phanerozoicstyle diagenetic system. Faults at Oklo played key roles by creating traps and/or paths for oil migration as well as by favourably positioning marine black shale in contact with deltaic sandstone hosts of the bitumen (Gauthier-Lafaye and Weber 1989; Nagy et al. 1991).

The main goal of the present study is to identify the origin of the CM associated with $\mathrm{U}$ minerals in the Kiggavik exploration camp located at the southeastern margin of the Paleo- to Mesoproterozoic Thelon Basin, building on the paragenetic context developed by (Riegler 2013; Riegler et al. 2014; Riegler et al. 2015; Sharpe 2013; Sharpe et al. 2015). The second focus is on the solid properties of the CM to better understand their very unusual spatial and textural associations with $\mathrm{U}$ oxide minerals.

\section{Geological setting}

AREVA Resources of Canada's Kiggavik Project (Figure 1) comprises several deposits at the advanced exploration stage, as follows from northeast to southwest: Kiggavik (formerly Lone Gull), Bong, End Grid and Andrew Lake. All of the high grade (>0.2\% U) zones, in which 
the main $U$ minerals are uraninite and coffinite, are surrounded by decametre-scale clay alteration envelopes mainly developed in lower amphibolite to upper greenschist facies Neoarchean metagreywacke of the Woodburn Lake group (Riegler et al. 2014; Lewry and Sibbald 1980). Unlike the basement-hosted deposits of the Athabasca Basin (Lewry and Sibbald, 1980), deposits in the Kiggavik Project area are not located along graphitic conductors although reactivated intersecting faults are important in both camps (Lewry and Sibbald, 1980; Fuchs and Hilger, 1989; Miller and LeCheminant, 1985; Jefferson et al., 2007; Tschirhart et al., 2014). During the alteration at Kiggavik, quartz was dissolved and all primary metamorphic silicate minerals (feldspars, muscovite, biotite, chlorite) were replaced by mainly illite and sudoite (Al-Mg di-trioctahedral chlorite) in various proportions. This alteration paragenesis is similar to that of many other Proterozoic unconformity-associated U deposits in Canada and Australia (Beaufort et al. 2005; Laverret et al. 2006; Hoeve and Quirt 1984; Polito et al. 2004; Riegler et al. 2014).

\section{Samples and Methods}

This study analyzed three representative samples from the Bong prospect that represent the two types of solid CM found in alteration halos around the U deposits of the Kiggavik Project area. The term "Diffuse CM" here refers to disseminated nodules, very variable in diameter from 10 to 1000 micrometers, in highly argillized rock and to diffuse impregnations of CM that stain and coat fractures and foliation planes. The term massive carbonaceous material (MCM) refers to veins of $\mathrm{CM}$ that form sub-millimetric coatings to vein fillings ranging from 1 up to $20 \mathrm{~mm}$ thick. Both types of solid CM are present only within the clay alteration zones. The MCM is represented by sample BG4238 from the hanging wall of a steeply dipping fault zone. The Diffuse CM is represented by samples BG4326, while the BG5101 sample is presenting a mix of both type with diffuse $\mathrm{CM}$ impregnation around a millimetric fracture 
filled with MCM. These samples were collected at 428, 316 and 286 meters respectively below the present erosion surface. No CM was observed in contact with uraninite in the high grade prospective ore zones. In much of the following discussion the simple term CM refers to undivided Diffuse and Massive CM, and analytical results are combined for the two, as the nodules are presenting the same $\mathrm{U}$ association as the more massive material. It must be noted that only the more massive material, typically from veinlets can easily be extracted and is abundant enough to carry detailed microstructural studies.

A D8 Advance Brucker diffractometer equipped with a $\mathrm{Cu}$ anode and a LynxEye detector were used for X-ray diffraction. The XRD system used a Ni-filtered $\mathrm{Cu} \mathrm{K}^{1+2}$ radiation and a soller slit on the incident beam, and analytical conditions were set with a $40 \mathrm{kV}$ acceleration tension and $40 \mathrm{~mA}$ current, and $1^{\circ}$ fixed divergence slit. Data collection scan parameters were $2-65^{\circ} 2 \theta$ (oriented mounts) or $5-65^{\circ} 2 \theta$ (random mounts) both with a $0.02^{\circ} 2 \theta$ step, and 2 and 4 seconds counting time, respectively.

Raman analyses were performed using a Horiba Jobin Yvon Labram HR800UV confocal microscope (x 100 objective lense) equipped with a CCD detector. The scanning parameters for each Raman spectrum were taken as $90 \mathrm{~s}$. Four scans were summed to provide a better signal to noise ratio. An Ar laser $(514.5 \mathrm{~nm})$ was used at a power of $0.05 \mathrm{~mW}$ on the sample, in a backscattering configuration. The measurements were made in the wave number range 50 to $4000 \mathrm{~cm}^{-1}$. The spectral resolution is $1.5 \mathrm{~cm}^{-1}$. Measurements were made on various fragments of raw material in order to avoid signal bias due to orientation and polishing effects.

Chemical composition, morphology and texture were studied using a JEOL 5600 scanning electron microscope equipped with a Bruker energy dispersive X-ray spectroscopy detector (EDS). Analytical conditions for chemical mapping were as follows: accelerating voltage 15 
$\mathrm{kV}$, probe current $1 \mathrm{nA}$, working distance $16.7 \mathrm{~mm}$, and counting time 5 minutes. The microanalysis system was calibrated for major elements using synthetic and natural oxides and silicates $\left(\mathrm{MnTiO}_{3}\right.$, hematite, albite, orthoclase, and diopside), and corrections were made using a ZAF program. Neither $\mathrm{C}$ nor Au coating was applied to the samples.

Microstructural analysis were conducted by TEM (Bright Field and High Resolution) and by STEM (High-Angle Annular Dark-Field (HAADF) or Z contrast) using a JEOL 2200-FS microscope (Schottky-FEG, $200 \mathrm{kV}$ ) fitted with an omega filter. The samples were dispersed in ethanol, and the suspension was draped on a carbon-film copper grid.

Whole rock geochemical analyses were obtained from the SARM (Service d'Analyses des Roches et Minéraux), Nancy, France, using protocols established in (Carignan et al. 2001).

The carbon isotopic composition $\left(\delta^{13} \mathrm{C}\right)$ of the $\mathrm{CM}$ was determined the Stable Isotope Laboratory of Geosciences Rennes using an elemental analyzer (EA-CE 1500 NA, Carlo Erba) coupled with an isotope ratio mass spectrometer (IRMS) (VG Isoprime). All the samples were previously acidized with $1 \mathrm{~N} \mathrm{HCl}$ in order to remove any carbonate. Tin capsules were used for sample loading. The $\delta^{13} \mathrm{C}$ values are expressed as the relative deviations between the measured ${ }^{13} \mathrm{C} /{ }^{12} \mathrm{C}$ ratio $\left(\mathrm{R}_{\text {sample }}\right)$ and the ${ }^{13} \mathrm{C} /{ }^{12} \mathrm{C}$ ratio of the international standard Vienna Pee Dee Belemnite (V-PDB) $\left(\mathrm{R}_{\text {standard }}\right)$, as follows: $\delta^{13} \mathrm{C}(\%)=$ $\left[\left(R_{\text {sample }} / R_{\text {standard }}\right)-1\right] \times 1000$. The accuracy on $\delta^{13} \mathrm{C}$ values measured is better than $\pm 0.2 \%$, based on repeated measurements.

\section{Petrography}

The $\mathrm{CM}$ are exclusively present within the clay alteration envelopes surrounding the $\mathrm{U}$ mineralization. Macroscopically, the MCM are dark grey to black, relatively competent and 
brittle with concoïdal fractures, filling millimetric to centimetric veinlets occuring at the walls of microfaults gouges (Figure 2a). The Diffuse CM micro- to millimetric nodules are disseminated in the illite- and sudoite-rich clay matrix (Figure 2a, 2c), and are also abundant in the walls of fractures filled with MCM (Figure2a, 2b). The petrographic relation of the CM developed within and crosscutting the illite and sudoite-rich alteration matrix suggests that these phases are cogenetic (Figure 2c). Then, the both types of CM might also be cogenetic. However, as the main ore is generally poor in $\mathrm{CM}$, the paragenetic relationships with the main ore remain unclear. In places thin coatings of uraninite occupy the walls of open fractures that are well developed in the $\mathrm{CM}$ nodules but terminate at the interface of the nodules with the enclosing clay matrix (Figure $\mathbf{2 b}, \mathbf{c}$ ). Uraninite is also disseminated within the MCM as minute euhedral crystals, commonly partially replaced by coffinite and organized into pseudo concentric rings. Overall the $\mathrm{CM}$ contains qualitatively elevated $\mathrm{U}, \mathrm{Fe}, \mathrm{S}$ and $\mathrm{Cu}$ (Figure 2d and f). Finally, oblate voids (possible dissolution pits) a few tens of micrometers across are located at the surface of the MCM (Figure 2e).

\section{Results}

\subsection{Geochemistry and elemental distributions in the MCM}

The average whole rock chemistry and carbon isotope values for the Bong MCM are listed in Table 1. The BG4238 sample contain in average up to $66 \%$ carbon and record highly negative isotopic composition with $\delta^{13} \mathrm{C}_{\text {org }}$ of $-39.1 \%$. Such value has also been observed in carbonaceous mineralized nodules in samples from Bong Uranium deposit in the same ara (Sharpe et al., 2015). The low Al, K, and Mg amounts are consistent with the absence of clay minerals within the MCM. The $\mathrm{Si}$ is associated with coffinite. $\mathrm{Cu}$ and $\mathrm{U}$ concentrations of MCM in the Bong alteration halo are particularly high, respectively 1 and $7.2 \%$, much higher than elsewhere in the Kiggavik area (Riegler et al. 2015), whereas other trace elements around 
Bong are negligible. The REE abundance could be related to the presence of uraninite, however the positive Eu anomaly $\left(\mathrm{Eu} / \mathrm{Eu}^{*}=\mathrm{Eu}_{\mathrm{N}} /\left(\mathrm{Sm}_{\mathrm{N}}+\mathrm{Gd}_{\mathrm{N}}\right)^{0.5}\right)$ of 2.17 is unusual compared to chondrite normalized whole rock REE patterns from other unconformity-related U deposits (Fayek and Kyser 1997) (Figure 3).

\subsection{X-Ray Diffraction}

Despite the overall high concentration of $\mathrm{C}$ (up to $66.3 \%$ ) and its macroscopic aspect, randomly oriented powders of MCM do not exhibit any characteristic XRD reflection. This suggests an amorphous structure. Moreover, similar results were obtained on MCM separates (via ultracentrifugation) on oriented mounts for the $<5 \mu \mathrm{m}$, and $<0.1 \mu \mathrm{m}$ size fractions (Figure 4). The only minerals identified are uraninite $\left(\mathrm{UO}_{2}\right)$, coffinite $\left(\mathrm{U}\left(\mathrm{SiO}_{4}\right)_{1-\mathrm{X}} \mathrm{OH}_{4 \mathrm{x}}\right)$, chalcopyrite $\left(\mathrm{CuFeS}_{2}\right)$, johannite $\left.\left[\mathrm{Cu}\left(\mathrm{UO}_{2}\right)\left(\mathrm{SO}_{4}\right)_{2}(\mathrm{OH})_{2} \cdot 8 \mathrm{H}_{2} \mathrm{O}\right)\right]$ and studtite $\left[\mathrm{UO}_{4} \cdot 4 \mathrm{H}_{2} \mathrm{O}\right]$ with reference to type XRD data of (Walenta 1974).

In addition, the XRD pattern of a $<0.1 \mu \mathrm{m}$ fraction oriented mount presents a broad baseline and a weak signal that indicates either an amorphous or very poorly organized structure along the $\mathrm{c}$ axis (i.e. without enough layers coherently stacked to diffract X-rays). Considering the macroscopic observations, the XRD pattern calls into question the type of bonds between the carbon atoms as well as the structure of the MCM. Consequently, Raman spectroscopy and transmission electron microscopy appear to be the most suitable techniques to probe the structure of $\mathrm{C}-\mathrm{C}$ bonds and the spatial organization of the $\mathrm{CM}$ respectively.

\subsection{Raman spectroscopy}


The Raw Raman spectra obtained on MCM show two pronounced bands at 1338 (D) and $1601(\mathrm{G}) \mathrm{cm}^{-1}$ as well as a relatively marked fluorescence responsible for the moderate baseline hiding the second order Raman bands (overtone) in the $2000-4000 \mathrm{~cm}^{-1}$ range (Figure 5). The RAMAN spectra are consistent throughout the MCM sample, and show no variation either in band position or intensity ratio. Of these two bands, the first one is broad and relatively intense, and can be attributed to disordered carbons and edge effects (D band) whereas the second, moderately intense but still broad band can be attributed to graphite (G band) linked to the $\mathrm{sp}^{2} \mathrm{C}-\mathrm{C}$ configuration of the (ab) graphene planes (Chu and Li 2006; Jehlička et al. 2003; Tuinstra and Koenig 1970b). These two bands present a significant shift from the pure and well ordered graphite D and $\mathrm{G}$ bands at 1355 and $1575 \mathrm{~cm}^{-1}$, respectively, in which the $\mathrm{G}$ band is extremely intense, well defined, and dominant over the $\mathrm{D}$ band. Finally, the shift toward higher wavelength values of the $G$ band appears to represent the effect of the crystallites size diminution (Tuinstra and Koenig 1970a), whereas the band intensity ratio $I_{D} / I_{G}(0.54)$ gave an in-plane crystallite size (La), ranging from 2 to $30 \mathrm{~nm}$ using two empirical formulae from (Knight and White 1989; Cancado et al. 2006).

In addition, spectral decomposition using the pseudo Voigt function identifies four different components at $1188,1334,1510$ and $1601 \mathrm{~cm}^{-1}$, with a reconstituted fitted profile (grey line) reasonably matching the original spectrum (Figure 5). The graphite $G$ and D bands are assigned to the 1334 and $1601 \mathrm{~cm}^{-1}$ wave numbers, whereas the $1188 \mathrm{~cm}^{-1}$ (D4 band) is assigned to disorder in the graphitic-like lattice and the $1510 \mathrm{~cm}^{-1}$ (D3 band) to an amorphous component in the signal (Sadezky et al. 2005; Al-Jishi and Dresselhaus 1982; Dippel and Heintzenberg 1999).

\subsection{Transmission electron microscope study of the MCM}


TEM analysis provided microstructural information. The general view in Figure 6a shows that the MCM consists of carbon layers (graphene-like layer), embedding numerous nanoparticles randomly distributed, with size ranging from 5 to $50 \mathrm{~nm}$. The HRTEM image Figure 6a also illustrates the amorphous structure of a graphene-like layer in agreement with XRD experiments (Figure 4). The crystalline structure of the nanoparticles is shown on the HRTEM image in Figure 6b. The corresponding Fast Fourier Transform (FFT) (Figure 6c) shows spots with fringe spacing of $3.1 \AA$ and an angle of $70^{\circ}$ between the two sets of fringes. This experimental result agrees with the $d\{111$ planes of the uraninite cubic structure. The two other spots correspond to fringe spacings of $1.9 \AA$ and $2.73 \AA$ of the $d\{022\}$ and $d\{002\}$ respectively showing that the zone axis of the particle is $\langle 110\rangle$. The HAADF-STEM results show that the uraninite nanocrystals range in size from a few nanometers up to a few hundred of nanometres. Lastly, the diffraction pattern in several areas of the MCM shows a preferential orientation which could represent the $\{111\}$ planes of uraninite (Figure 6d).

\section{Discussion}

Microstructures and geochemistry of CM from unconformity related U deposits are rarely considered together in the literature. However, their complete characterization herein for the Proterozoic unconformity related deposits of the Kiggavik camp provides insights on their relationships with the paragenesis of spatially associated $U$ oxide minerals.

\subsection{Three-dimensional organization of the MCM}

X-ray and electron diffraction patterns, as well as the HRTEM images of the MCM indicate no significant coherent carbon layer stacking along the c-axis of the MCM material. Moreover, the Raman signal $\left(\mathrm{I}_{\mathrm{D}} / \mathrm{I}_{\mathrm{G}}\right.$ band intensity ratio, band positions and shapes) indicates 
that the $\mathrm{CM}$ is predominantly formed of $\mathrm{sp}^{2}$-bonded carbon, implying a predominant organization in the $(\mathrm{ab})$ plane, thereby constituting films with a graphene structure. Therefore, the CM formed by stacking layers of nanometric graphene crystallites with a low degree of organization along the c-axis to form a graphite-like structure. In addition, the pronounced fluorescence observed in the Raman spectrum could imply the presence of C-H bonds in the carbon films as polymer-like amorphous carbon, and may explain the $\mathrm{H}$ abundance in the $\mathrm{CM}$ (Godet et al. 1998). Such bonds are known to give peculiar properties (optical absorption, electron affinity) to carbon films and were thus scrutinized in recent studies with respect to their possible industrial applications (Chu and Li 2006). Overall, it appears that the Kiggavik Project CM shares structural and/or compositional attributes with amorphous carbon, activated charcoal, fluid deposited graphite and graphite nano-particules, as do CM of other Proterozoic U deposits (Tuinstra and Koenig 1970a; Chu and Li 2006; Wang et al. 1989; Calderon Moreno et al. 2000; Kribek et al. 1999; Luque et al. 1993).

\subsection{Nanoscale properties of the $C M$ and possible implications for $U$ precipitation}

TEM observations indicate that euhedral nanocrystals of uraninite are disseminated within the amorphous CM. Notably, the sizes of the graphene in plane crystallite, and uraninite nanocrystals are in the same order of magnitude. Such a close association between the CM and uraninite could be related to orientation-controlled growth on the graphene layer. Specifically the epitaxial growth of uraninite could be due to the match between uraninite lattice on the $\{111\}$ plane, and the (0001) hexagonal lattice of graphene.

The big question is whether the deposition of the CM was contemporaneous with primary uraninite deposition during ore formation, or with secondary uraninite related to one or more 
remobilization events (in any case both require reducing conditions to precipitate) as suggested in Sharpe et al. (2015). In such a process, the enhanced surface area of the CM could have acted as a favourable site for nucleation of uraninite crystals. Such a process would explain the disseminated low grade $\mathrm{U}$ found widely in alteration zones where CMs are present. Certainly the generation of $\mathrm{CM}$ and $\mathrm{U}$ oxide minerals took place in turns and repeatedly as shown in Figure $\mathbf{2 d}$.

\subsection{CM properties and high dose rate}

According to the high U-content (about 7\%) and the specific tridimensional organization of the MCM (i.e., disseminated U-bearing nanocrystals between randomly organized graphenlike carbon layers), the present structure of the $\mathrm{CM}$ could be a consequence of irradiation experienced by the primary organic carbon (e.g. graphite) over a time period assumed to be greater than one billion years. Two types of radiation can be considered i.e. ionizing radiations vs heavy ions. Assuming a dose rate from ionizing radiation of $3040 \mathrm{mGy} / \mathrm{ka}$ per ppm of $U$ (Aitken 1985), the cumulative dose would have been $2.1310^{11} \mathrm{~Gy}$. The amorphisation dose of graphite by ionizing radiation is estimated at $10^{12}-10^{13} \mathrm{~Gy}$, after Kinoshita et al. (1989). Consequently, the ionizing radiation probably did not amorphize the CM. On the other hand calculation with the SRIM code (Ziegler et al. 1985) indicates that alpha recoils (simulated herein by $\mathrm{Pb}$ ions of $300 \mathrm{keV}$ ) would have induced a dose in the order of 33 displacements per atom (dpa) in the CM. Furthermore, experiments with heavy ions such as $\mathrm{Ar}^{+}$or $\mathrm{Xe}^{+}$lead to amorphization of graphite within a few dpa (Abe et al. 1997). Consequently, irradiation by heavy recoil nuclei over 1 billion years would have been readily able to amorphize the graphite over short distances from $U$ sources. Only $U$ is considered for the Kiggavik Project because thorium and potassium concentrations are negligible. The 
intimate structural association of $U$ nanoparticles with carbonaceous layers supports the assumption of metamictization because it implies that short range heavy recoils could have been very efficient. However, as graphite is chemically inert, the hypothesis of uraninite epitaxis and of a subsequent graphite amorphization would imply that the initial graphite structure and its physico-chemical properties differed drastically from those found in the present samples.

\subsection{Origin and genesis of the $\mathrm{CM}$}

Graphite is the end product of thermal maturation of organic matter and is known to retain any crystalline order acquired during prograde metamorphism (Luque et al. 1993). Therefore, the very poor crystallinity of the Kiggavik MCM relative to the regional greenschist to amphibolite metamorphic facies, and its spatial restriction to within the alteration halos argue for precipitation from hydrothermal fluids during mineralization (Pasteris and Wopenka 1991; Wopenka and Pasteris 1993; Lewry and Sibbald 1980). From this perspective the CM from Kiggavik does not resemble graphitic material formed by greenschist or higher grade metamorphism (Wopenka and Pasteris 1993). The Kiggavik CM is however similar to Neoproterozoic, vein hosted, brittle solid bitumen or graphitoid materials described in hydrothermal environments such as around the Klecany intrusive complex in Bohemia (Jehlička et al. 2003). It is also quite similar to the shungite found in Karelia (in terms of its plane crystallite (La): $40 \mathrm{~nm}$; disorder) (Jehlička et al. 2005; Wopenka and Pasteris 1993), and to graphite from laboratory hydrothermal experiments (Luque et al. 1998).

\subsection{Geochemical signature and redox properties}


The MCM and diffuse $\mathrm{CM}$ found at Kiggavik are similar in term of texture, petrographic relationship within the alteration halo surrounding mineralization zones, and low $\delta^{13} \mathrm{C}$ values (-49.0 to $-31.0 \%$ range), to those already identified as solid bitumens in the Athabasca Basin unconformity-related U deposits (Leventhal et al. 1987; Sangély et al. 2007). In addition, their restriction to within the alteration haloes (as fracture fillings or disseminated in the clay matrix) supports precipitation coeval with the hydrothermal alteration and U mineralization.

Two intriguing differences that set apart the Kiggavik CMs are their very high associated U and $\mathrm{Cu}$ concentrations and their positive Eu anomaly. However, uraninite can incorporate significant amounts of $\mathrm{REE}$, therefore a positive $\mathrm{Eu}$ anomaly in the whole rock can be extended to a Eu anomaly in uraninite (Fayek and Kyser, 1997) and interpreted as a signature of an oxidizing fluid (Henderson 1984). Thus, a very significant reduction must have taken place to precipitate uraninite and chalcopyrite. Such drastic, local reducing conditions could have been induced or controlled by nanoscopic properties of the CM.

\section{Conclusions}

We propose that the petrographic and textural relationships with alteration minerals, the isotopic ratios, and the crystallographic properties of the $\mathrm{CM}$ around the Kiggavik deposits resulted from abiotic, hydrothermal synthesis. This hypothesis links the Kiggavik CM to the already established paragenesis which records hydrothermal alteration of the Neoarchean metasedimentary basement and transport and deposition of U. In the Thelon Basin at Kiggavik, as well as in various locations in the Athabasca Basin (Sangély et al. 2007; Landais and Dereppe 1985; Leventhal et al. 1987; Alexandre and Kyser 2006), the CMs are considered to be a key component and distinctive exploration tracer of the succession of hydrothermal events responsible for primary and/or secondary U deposition events. 
In more general terms we suggest that the solid properties of $\mathrm{CM}$ provide a favorable environment for $\mathrm{U}$ oxide and metallic sulfide precipitation. These nanoscale solid properties could also help reassess both unusual and well known associations between carbon compounds and metallic minerals in a wide range of other geological environments. Finally, these results provide new perspectives on ore paragenesis developed using standard optical and microbeam techniques, and highlight the need for integrated studies of such materials.

\section{Acknowledgments}

The authors are grateful to AREVA NC for sponsoring this study. We also thank Nadia Guignard at the IC2MP Service Mesures Physiques for her precious help with the RAMAN spectroscopy. Thanks go also to Dr Charlie Jefferson for his thorough review and comments during the preparation of the manuscript.

\section{References}

Abe $H$, Naramoto $H$, Iwase A, Kinoshita C (1997) Effect of damage cascades on the irradiationinduced amorphization in graphite. Nuclear Instruments and Methods in Physics Research B 127/128:681-684.

Aitken MJ (1985) Thermoluminscence dating. Academic Press, London and Orlando and Montreal.

Al-Jishi R, Dresselhaus G (1982) Lattice-dynamical model for graphite. Physical Review B 26:45144522.

Alexandre P, Kyser TK (2006) GEOCHEMISTRY OF URANIFEROUS BITUMEN IN THE SOUTHWEST ATHABASCA BASIN, SASKATCHEWAN, CANADA. Econ Geol 101:1605-1612. doi: 10.2113/gsecongeo.101.8.1605.

Beaufort D, Patrier P, Laverret E, Bruneton P, Mondy J (2005) Clay Alteration Associated with Proterozoic Unconformity-Type Uranium Deposits in the East Alligator Rivers Uranium Field, Northern Territory, Australia. Econ Geol 100:515-536.

Calderon Moreno JM, Swamy SS, Fujino T, Yoshimura M (2000) Carbon nanocells and nanotubes grown in hydrothermal fluids. Chemical Physics Letters 329:317-322. doi: http://dx.doi.org/10.1016/S0009-2614(00)01017-4.

Cancado LG, Takai K, Enoki T, Endo M, Kim YA, Mizusaki H, Jorio A, Coelho LN, Magalhaes-Paniago R, Pimenta MA (2006) General equation for the determination of the crystallite size $L$ [sub a] of nanographite by Raman spectroscopy. Applied Physics Letters 88:163106.

Carignan J, Hild P, Mevelle G, Morel J, Yeghicheyan D (2001) Routine analyses of traceelements in geological samples using flow injection and low pressure on-line liquid chromatography 
coupled to ICP-MS: a study of geochemical reference materials BR, DR-N, UB-N, AN-G and GH. Geostand Geoanal Res 25:187-198.

Chu PK, Li L (2006) Characterization of amorphous and nanocrystalline carbon films. Materials Chemistry and Physics 96:253-277. doi: http://dx.doi.org/10.1016/j.matchemphys.2005.07.048.

Curiale JA (1986) Origin of solid bitumens, with emphasis on biological markers results. Organic Geochemistry 10:559-580.

Dippel B, Heintzenberg J (1999) Soot characterization in atmospheric particles from different sources by NIR FT Raman spectroscopy. Journal of Aerosol Science 30, Supplement 1:S907-S908. doi: http://dx.doi.org/10.1016/S0021-8502(99)80464-9.

Fayek M, Kyser K (1997) Characterization of multiple fluid events and rare-earth-element mobility associated with formation of unconformity-type uranium deposits in the Athabasca Basin, Saskatchewan. Can Mineralog 35:627-658.

Foustoukos DI, Seyfried WE (2004) Hydrocarbons in Hydrothermal Vent Fluids: The Role of Chromium-Bearing Catalysts. Science 304:1002-1005. doi: 10.1126/science.1096033.

Gauthier-Lafaye F, Weber F (1989) The Francevillian (Lower Proterozoic) uranium ore deposits of Gabon. Econ Geol 84:2267-2285.

Gize AP (1999) Organic alteration in hydrothermal sulfide ore deposits. Econ Geol 94:967-979. doi: 10.2113/gsecongeo.94.7.967.

Godet C, Heitz T, Bourée JE, Drévillon B, Clerc C (1998) Growth and composition of dual-plasma polymer-like amorphous carbon films. J Appl Phys 84:3919-3932.

Henderson P (1984) Rare Earth Elements Geochemistry. Elsevier, Amsterdam.

Hoeve J, Sibbald TII (1978) On the genesis of the Rabbit Lake and other unconformity-type uranium deposits in Northern Saskatchewan, Canada. Econ Geol 73.

Hoeve J, Sibbald TII, Ramaekers P, Lewry JF (1980) Athabasca basin unconformity-type uranium deposits : a special class of sandstone-type deposits? In: Ferguson J, Goleby AB (eds) Uranium in the Pine Creek Geosyncline. International Atomic Energy Agency, Vienna, pp pp. 575-594.

Hoeve J, Quirt D (1984) Mineralization and host rock alteration in relation to clay mineral diagenesis and evolution of the Middle-Proterozoic Athabasca basin, Northern Saskatchewan, Canada Saskatchewan Research Concil Technical report. Saskatchewan Reasearch Council, pp 197.

Horita J (2005) Some perspectives on isotope biosignatures for early life. Chem Geol 218:171-186. doi: http://dx.doi.org/10.1016/j.chemgeo.2005.01.017.

Jehlička J, Urban O, Pokorný J (2003) Raman spectroscopy of carbon and solid bitumens in sedimentary and metamorphic rocks. Spectrochimica Acta Part A: Molecular and Biomolecular Spectroscopy 59:2341-2352. doi: http://dx.doi.org/10.1016/S13861425(03)00077-5.

Jehlička J, Frank O, Pokorný J, Rouzaud J-N (2005) Evaluation of Raman spectroscopy to detect fullerenes in geological materials. Spectrochimica Acta Part A: Molecular and Biomolecular Spectroscopy 61:2364-2367. doi: http://dx.doi.org/10.1016/j.saa.2005.02.014.

Kinoshita C, Nakai K, Matsunaga A, Shinohara K (1989) A study of electron irradiation-inducedamorphization and swelling of graphite through electron microscopy. Proc Japan Acad 65:182-186.

Knight DS, White WB (1989) Characterization of diamond films by Raman spectroscopy. Journal of Material Research 4:385-393.

Kribek B, Zak K, Spangenberg JE, Jehlicka J, Prokes S, Kominek J (1999) Bitumens in the late Variscan hydrothermal vein-type uranium deposit of Pribram, Czech Republic; sources, radiationinduced alteration, and relation to mineralization. Econ Geol 94:1093-1114. doi: 10.2113/gsecongeo.94.7.1093.

Kyser K, Wilson MR, Ruhrmann G (1989) Stable isotpoe contraints on the role of graphite in the genesis of unconformity-type uranium deposits. Can J Earth Sci 26:490-498. 
Landais P, Dereppe JM (1985) A chemical study of the carbonaceous material form the Carswell structure - The Carswell Structure Uranium deposits Geolgical Association of Canada SPecial Paper. Toronto, pp 165-174.

Laverret E, Patrier P, Beaufort D, Kister P, Quirt D, Bruneton P, Clauer N (2006) Mineralogy and geochemistry of the host-rock alterations associated with the Shea Creek unconformity-type uranium deposits (Athabasca basin, Saskatchewan, Canada) Part1. Spatial variation of illite properties. Clay Clay Miner 54:275-294.

Leventhal JS, Grauch RI, Threlkeld CN, Lichte FE, Harper CT (1987) Unusual organic matter associated with uranium from the Claude Deposit, Cluff Lake, Canada. Econ Geol 82:1169-1176. doi: 10.2113/gsecongeo.82.5.1169.

Lewry JF, Sibbald TII (1980) Thermotectonic evolution of the Chruchill province in Northern Saskatchewan. Tectonophysics 68:45-82.

Luque FJ, Barrenechea JF, Rodas M (1993) Graphite geothermometry in low and high temperature regimes: two case studies. Geological Magazine 130:501-511. doi: doi:10.1017/S0016756800020562.

Luque FJ, Pasteris JD, Wopenka B, Rodas M, Barrenechea JF (1998) Natural fluid-deposited graphite; mineralogical characteristics and mechanisms of formation. American Journal of Science 298:471-498. doi: 10.2475/ajs.298.6.471.

Mastalerz M, Bustin RM, Sinclair AJ, Stankiewicz BA (1995) Carbon-rich material in the Erickson hydrothermal system, northern British Columbia, Canada; origin and formation mechanisms. Econ Geol 90:938-947. doi: 10.2113/gsecongeo.90.4.938.

McCollom TM, Seewald JS (2006) Carbon isotope composition of organic compounds produced by abiotic synthesis under hydrothermal conditions. Earth and Planetary Science Letters 243:7484. doi: http://dx.doi.org/10.1016/j.epsl.2006.01.027.

McCollom TM (2013) Laboratory Simulations of Abiotic Hydrocarbon Formation in Earth's Deep Subsurface. Reviews in Mineralogy and Geochemistry 75:467-494. doi: 10.2138/rmg.2013.75.15.

Nagy B, Gauthier-Lafaye F, Holliger P, Davis DW, Mossman DJ, Leventhal JS, Rigali MJ, Parnell J (1991) Role of organic matter in containment of uranium and fissiongenic isotopes at the Oklo natural reactor. Nature 354:472-475.

Pagel M, Poty B, Sheppard SMF (1980) Contribution to some Saskatchewan uranium deposits from fluid inclusion and isotopic data In: Ferguson J, Goleby AB (eds) Uranium in the Pince Creek geosyncline. AEIA, Vienna, pp 639-654.

Pasteris JD, Wopenka B (1991) Raman spectra of graphite as indicators of degree of metamorphism. Can Mineralog 29:1-9.

Polito PA, KYSER TK, Marlatt J, Alexandre P, Bajwah Z, Drever G (2004) Significance of Alteration Assemblages for the Origin andEvolution of the Proterozoic Nabarlek Unconformity-Related Uranium Deposit,Northern Territory, Australia. Econ Geol 99:113-139. doi: 10.2113/gsecongeo.99.1.113.

Riegler T (2013) Système d'altération et minéralisation en uranium le long du faisceau structural Kiggavik - Andrew Lake (Nunavut, Canada): modèle génétique et guides d'exploration UFR Sciences Fondamentales et Appliquées. Université de Poitiers, Thèse de Doctorat, pp 244.

Riegler T, Wollenberg P, Lescuyer J-L, Quirt D, Beaufort D (2014) Alteration related to uranium deposits in the Kiggavik-Andrew Lake structural trend, Nunavut, Canada: new insights from petrography and clay mineralogy. Can Mineralog 52:27-45.

Riegler T, Quirt D, Beaufort D (2015) Spatial distribution and compositional variation of APS minerals related to uranium deposits in the Kiggavik-Andrew Lake structural trend, Nunavut, Canada. Miner Deposita.

Ruzicka VR (1996) Unconformity-associated uranium In: Eckstrand OR, Sinclair WD, Thorpe RI (eds) Geology of Canadian Mineral Deposits. Geological Survey Of Canada, pp 197-210. 
Sadezky A, Muckenhuber H, Grothe H, Niessner R, Pöschl U (2005) Raman microspectroscopy of soot and related carbonaceous materials: Spectral analysis and structural information. Carbon 43:1731-1742. doi: http://dx.doi.org/10.1016/j.carbon.2005.02.018.

Sangély L, Chaussidon M, Michels R, Brouand M, Cuney M, Huault V, Landais P (2007) Micrometer scale carbon isotopic study of bitumen associated with Athabasca uranium deposits: Constraints on the genetic relationship with petroleum source-rocks and the abiogenic origin hypothesis. Earth and Planetary Science Letters 258:378-396. doi: http://dx.doi.org/10.1016/j.epsl.2007.03.018.

Sharpe R (2013) The geochermistry and geochronolgy of the Bong uranium deposit, Thelon Basin, Nunavut, Canada Department of Geological Sciences. University of Manitoba, Winnipeg, Manitoba.

Sharpe R, Fayek M, Quirt D, Jefferson CW (2015) Geochronology and Genesis of the Bong Uranium Deposit, Thelon Basin, Nunavut, Canada. Econ Geol 110:1759-1777.

Shock E (1990) Geochemical constraints on the origin of organic compounds in hydrothermal systems. Origins Life Evol Biosphere 20:331-367. doi: 10.1007/bf01808115.

Tremblay LP (1972) Geology of the Beaverlodge Mining Area, Saskatchewan. Geol. Surv. Can., pp 265.

Tuinstra F, Koenig JL (1970a) Raman Spectrum of Graphite. The Journal of Chemical Physics 53:11261130.

Tuinstra F, Koenig JL (1970b) Characterization of Graphite Fiber Surfaces with Raman Spectroscopy. Journal of Composite Materials 4:492-499. doi: 10.1177/002199837000400405.

Ueno $Y$, Yoshioka H, Maruyama S, isozaki Y (2004) Carbon isotopes and petrography of kerogens in 3.5-Ga hydrothermal silica dikes in the North Pole area, Western Australia. Geochimica et Cosmochimica Acta 68:573-589.

Walenta K (1974) On Studtite and its composition. Am Mineralog 59:166-171.

Wang A, Dhamenincourt P, Dubessy J, Guerard D, Landais P, Lelaurain M (1989) Characterization of graphite alteration in an uranium deposit by micro-Raman spectroscopy, X-ray diffraction, transmission electron microscopy and scanning electron microscopy. Carbon 27:209-218. doi: http://dx.doi.org/10.1016/0008-6223(89)90125-5.

Wilson MR, Stasiuk LD, Fowler MG (2002) Post mineralization origin of organic matter in Athabasca unconformity-type uranium deposits, Saskatchewan, Canada Summary of Investigations. Saskachewan Geological Survey pp 6.

Wopenka B, Pasteris JD (1993) Structural characterization of kerogens to granulite-facies graphite; applicability of Raman microprobe spectroscopy. Am Mineralog 78:533-557.

Yeo G, Potter EG (2010) Review of reducing mechanisms potentially involved in the formation of unconformity-type uranium depoists and their relevance to exploration In: Survey SG (ed). Sask. Ministry of Energy and Resources, pp 13.

Ziegler JF, Biersack JP, Littmark U (1985) The stopping and range of ions in solids. Pergamon. 


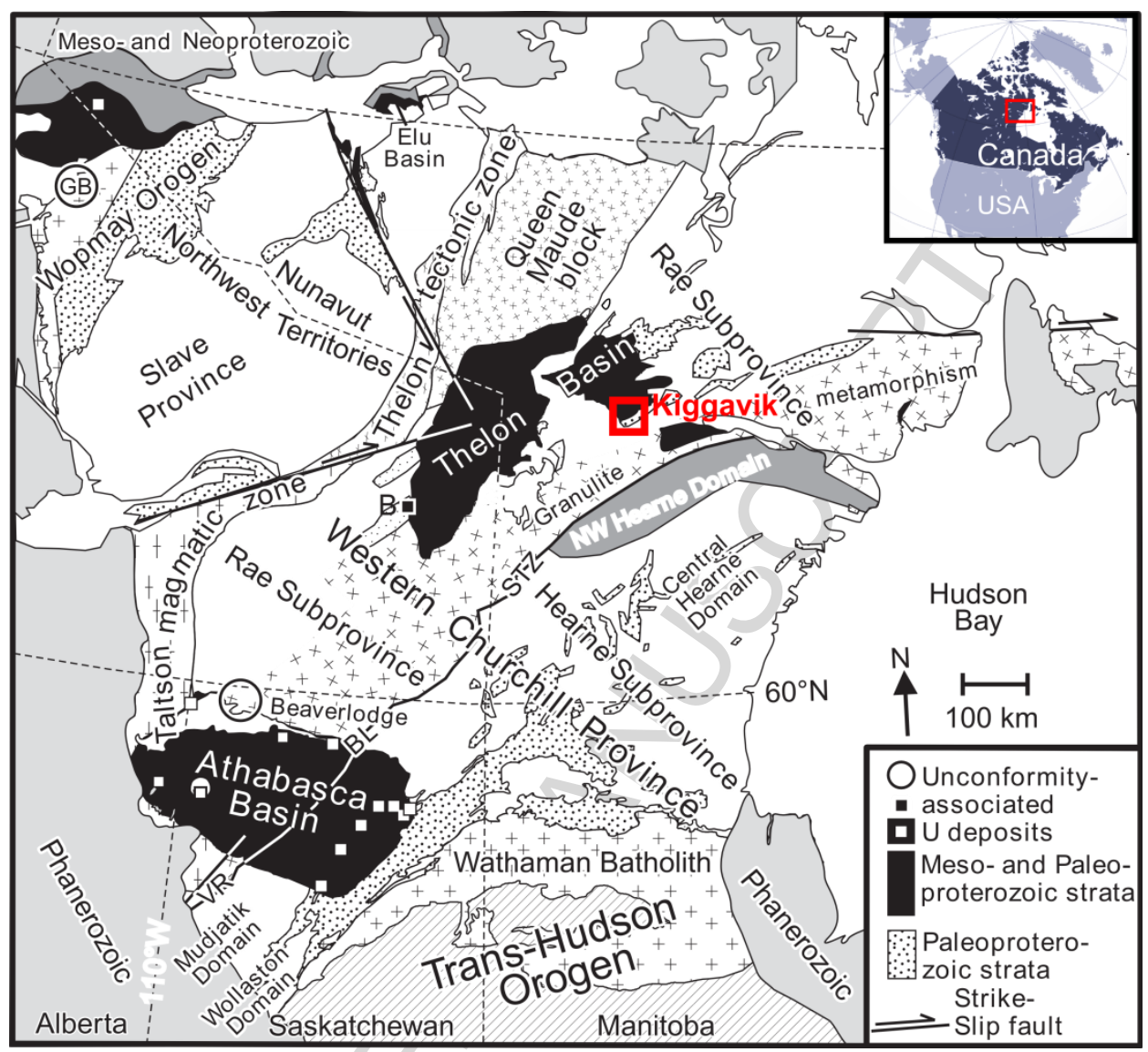

Figure 1: Geological context of the Kiggavik project, modified from Jefferson et al. (2007) 


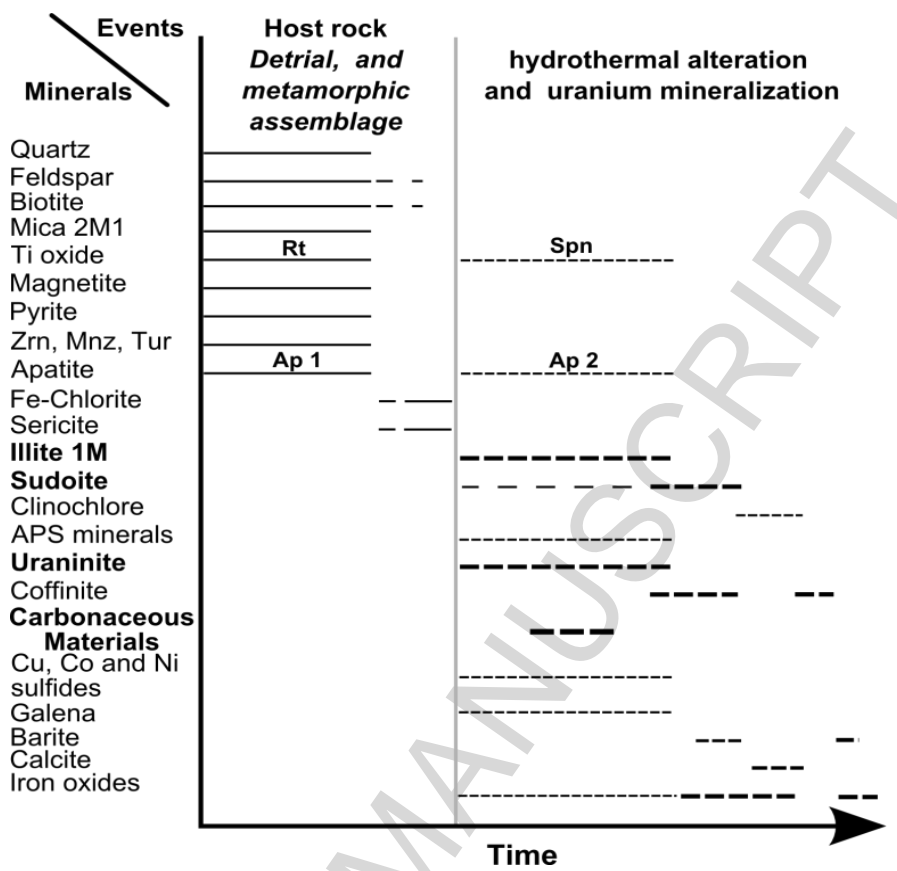

Figure 2: Simplified paragenetic sequence of alteration and uranium mineralization illustrating the association between carbonaceous materials and hydrothermal alteration. 

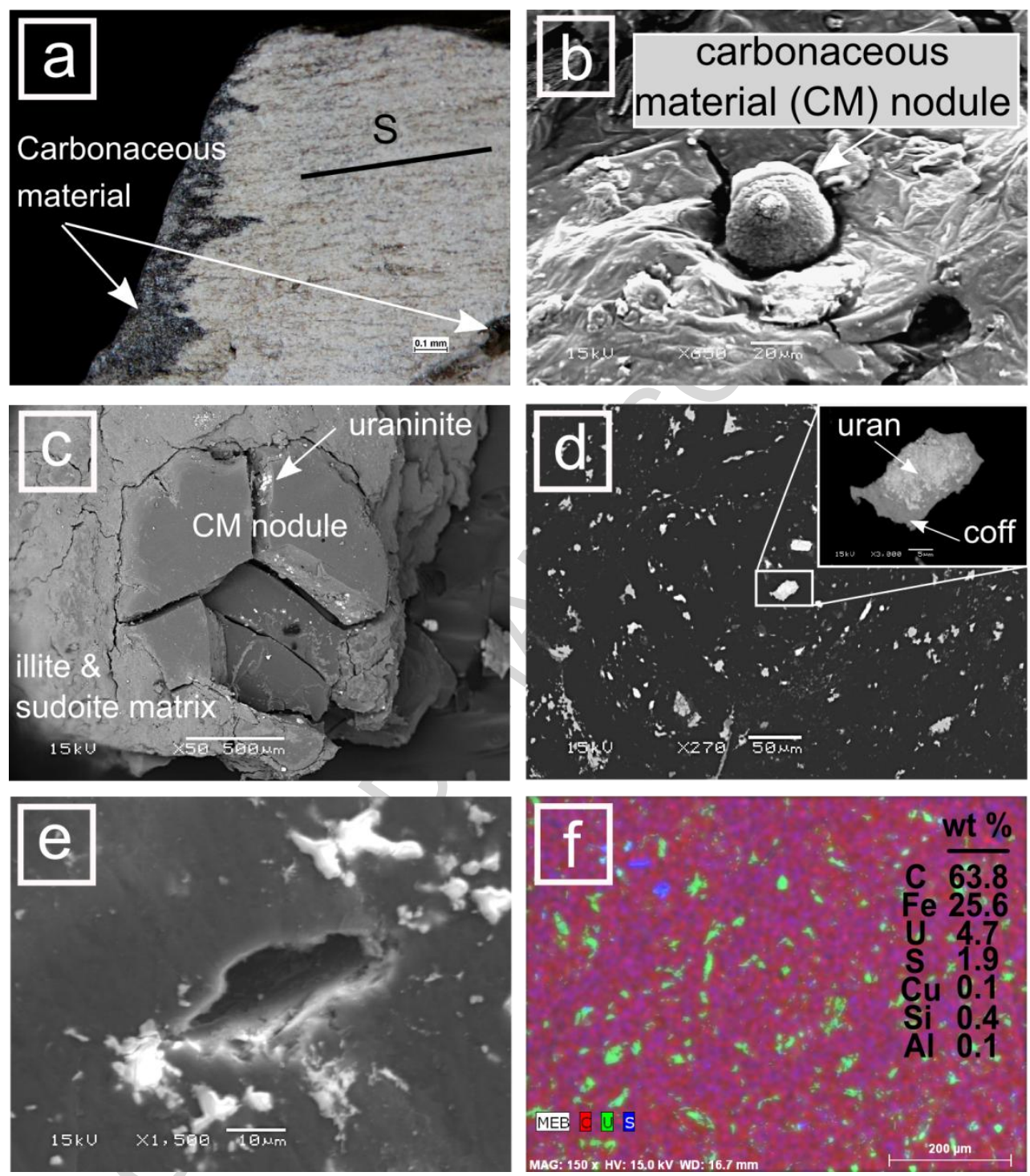

Figure 3: Examples of CM in the Bong prospect (Kiggavik Project). 2a: MCM along foliation planes and filling millimetric fractures in altered foliated metagreywacke, S: foliation, BG5101. 2b: Diffuse CM nodule in argillized metagreywacke BG4326. 2c: Diffuse CM nodule in a matrix of illite and sudoite at the wall of a centimtric vein of MCM. Open micro-fracture planes are dotted with uraninite (BG4238). 2d: Disseminated uraninite (uran) partially replaced by coffinite (coff) and in MCM. Uraninite crystals are forming from pseudo concentric rings from the center of the SEM image. 2e: Oblate void in MCM. 2f: elemental map for carbon (red), $\mathrm{U}$ (green) and sulfur (blue) in MCM. The wt \% column lists representative average element abundances within the micro-mapped area shown here. 


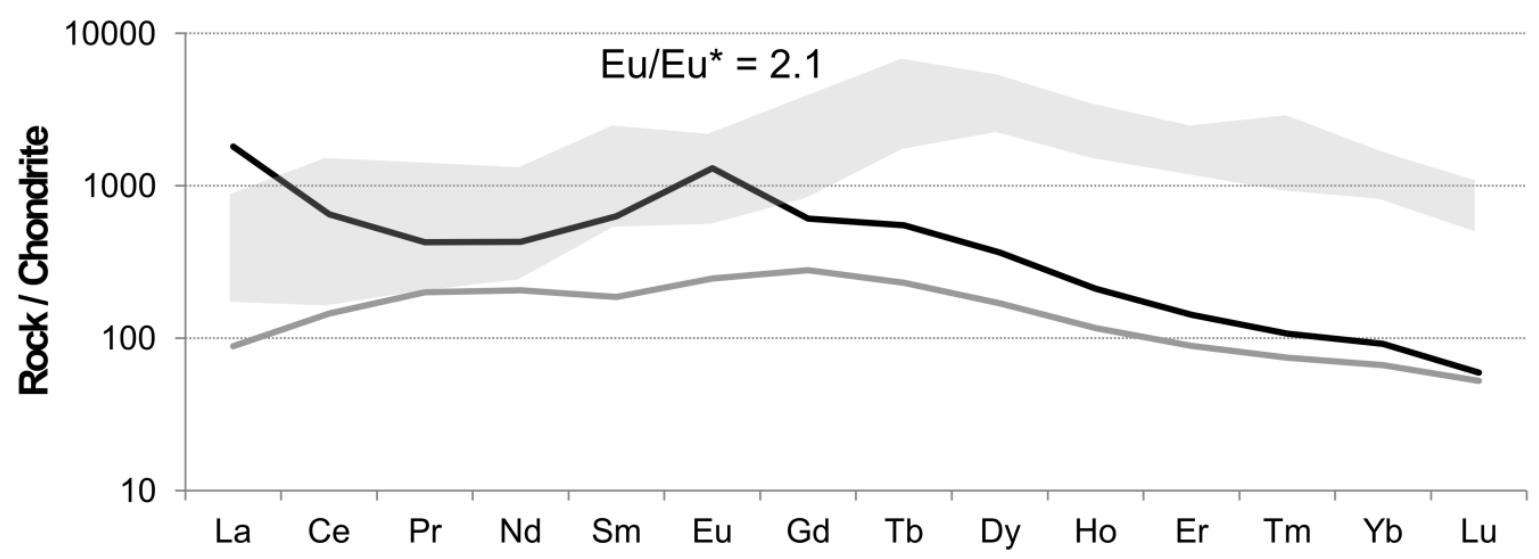

Figure 4: Average chrondite normalized REE patterns of U mineralization associated with MCM, (BG4238 sample) (bold back line). The gray shaded area represents the range of uraninite REE patterns of uraninite samples from the Eagle Point, McArthur River and Key Lake deposits, from (Fayek and Kyser, 1997). The light gray line represents one whole-rock sample of high grade uraninite from Kiggavik (Riegler et al. 2015). 


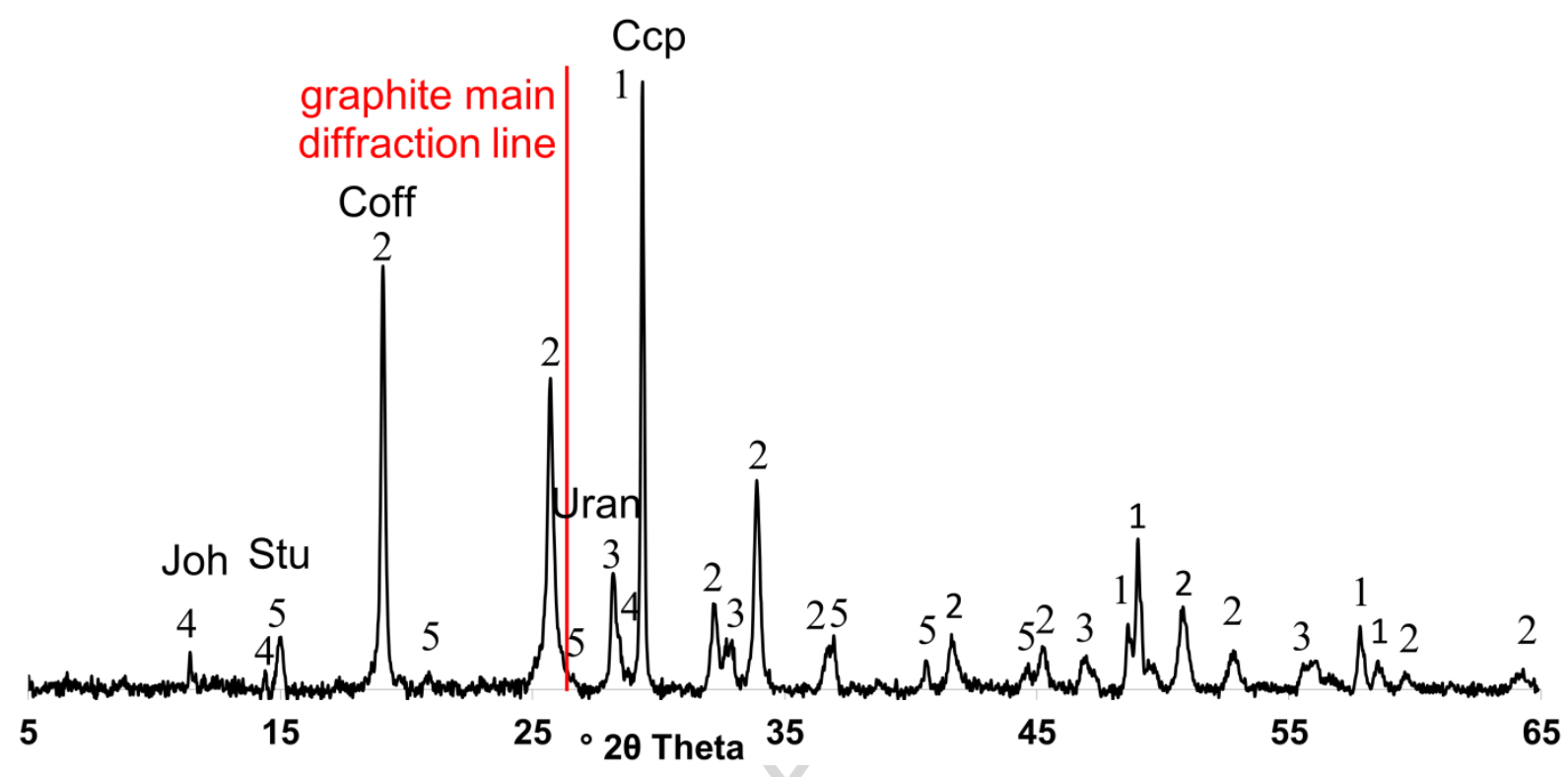

Figure 5: Whole rock $<50 \mu \mathrm{m}$ randomly oriented powder XRD diffractogram of MCM, (sample BG4238), 5-65 $2 \theta$ scan, 0.02 stepsize and 4 seconds counting time). Abbreviations, Ccp (1): Chalcopyrite; Coff (2): coffinite; Uran (3) uraninite; Joh (4): johannite and Stu (5): studtite. 


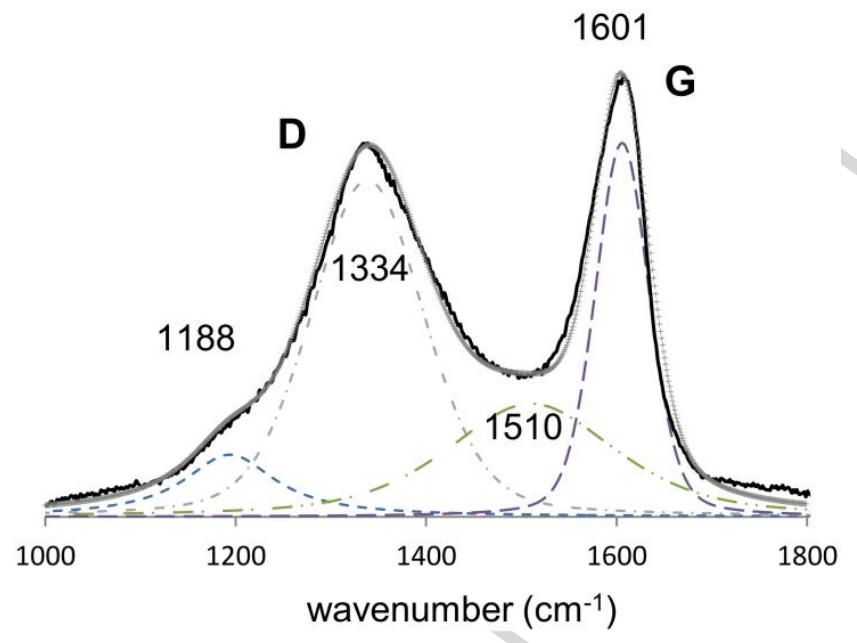

Figure 6: Raman spectra of MCM: raw signal (jagged black line), the four components (dotted lines) of the decomposed Raman spectrum, and the best fit (crosses) after linear background correction. See text for further explanation of graphite bands D and G. 

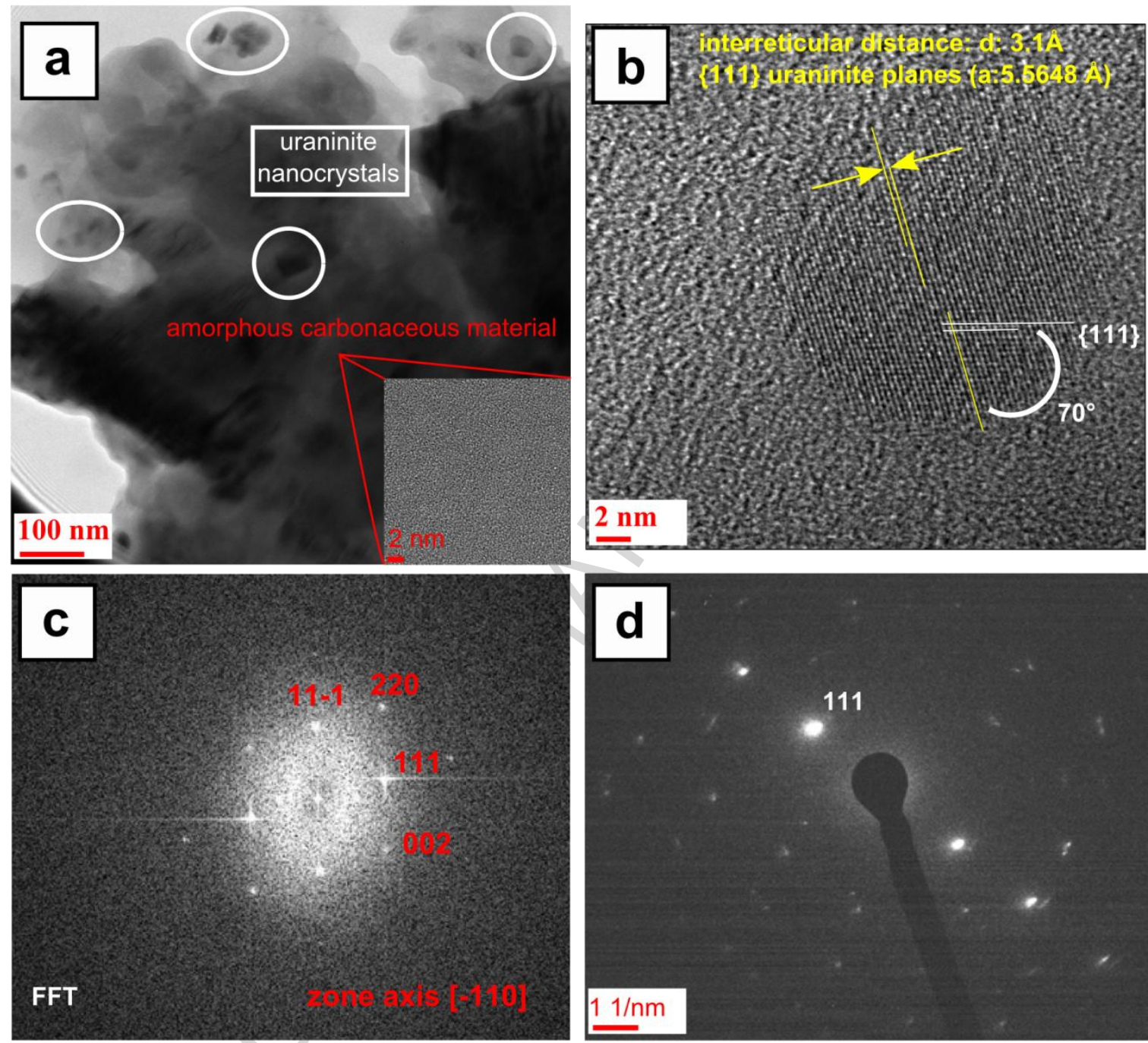

Figure 7: Transmission electron microscope images of MCM: (a) general view showing the graphene layer and numerous nanoparticles; and HRTEM images showing the amorphous carbon matrix, (b-c), HRTEM image of the nanoparticule and the corresponding FFT in agreement with the cubic structure of the uraninite. (d) Electron diffraction image of a uraninite micro-crystal in the graphene-like matrix. 
Table 1: Whole-rock and organic carbon isotopic compositions $\left(\delta^{13} \mathrm{C}\right.$ relative to PDB) of the BG4238 MCM sample.

\begin{tabular}{|c|c|c|c|c|c|c|c|c|c|c|c|c|c|c|}
\hline L.O.I & C & $S$ & H & $\mathrm{Fe}_{2} \mathrm{O}_{3}$ & $\mathrm{SiO}_{2}$ & $\mathrm{Al}_{2} \mathrm{O}_{3}$ & $\mathrm{CaO}$ & $\mathrm{TiO}_{2}$ & $\mathrm{P}_{2} \mathrm{O}_{5}$ & $\mathrm{~K}_{2} \mathrm{O}$ & MgO & $\mathrm{MnO}$ & $\mathrm{Na}_{2} \mathrm{O}$ & $\delta C \%$ \\
\hline \multirow[t]{3}{*}{83.5} & 66.3 & 4.68 & 3.9 & 3.44 & 1.94 & 0.51 & 0.30 & 0.13 & 0.12 & 0.08 & 0.06 & 0.01 & $<$ L.D. & -39.1 \\
\hline & U & $\mathrm{Cu}$ & $\mathrm{Pb}$ & $\mathbf{Y}$ & Co & As & V & $\mathbf{W}$ & $\mathrm{Ni}$ & Th & Mo & $\mathrm{Nb}$ & $\mathrm{Ta}$ & \\
\hline & 71910 & 10020 & 2193 & 247.3 & 142.1 & 139.0 & 32.0 & 25.9 & 16.7 & 11.8 & 9.5 & 3.0 & 0.1 & \\
\hline La & $\mathrm{Ce}$ & $\mathrm{Pr}$ & $\mathrm{Nd}$ & $\mathrm{Sm}$ & Eu & Gd & Tb & Dy & Ho & Er & $\mathrm{Tm}$ & $Y b$ & Lu & ¿REE \\
\hline 441.9 & 413.7 & 40.9 & 202.5 & 97.0 & 75.5 & 124.6 & 20.6 & 92.5 & 12.0 & 23.7 & 2.7 & 15.1 & 1.5 & 1564.3 \\
\hline
\end{tabular}




\section{Highlights}

- Hydrothermal carbonaceous material (CM) associated with a Proterozoic U deposit

- First description of CM in the Thelon Basin area of Nunavut

- Unusual association of massive and disseminated $\mathrm{CM}$ with $\mathrm{U}$ oxide minerals

- Natural carbon nanoscale structures controlled crystal nucleation and growth 